\title{
Green infrastructure: a planning concept for the urban transformation of former coal-mining cities
}

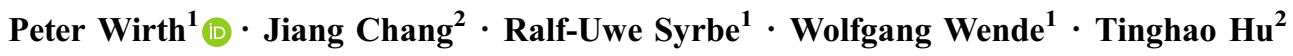

Received: 18 August 2017/Revised: 19 February 2018/Accepted: 13 March 2018/Published online: 24 April 2018

(C) The Author(s) 2018

\begin{abstract}
Green infrastructure is a concept aimed at realizing a strategically planned network of valuable natural and seminatural areas, designed and managed to deliver a wide range of ecosystem services and to protect biodiversity in rural and urban settings. In the general post-mining context of China and Germany, this paper suggests and outlines an approach that combines green infrastructure with specific concepts of post-mining landscapes. While Germany has a long tradition of post-mining restoration, concepts of green infrastructure are still poorly developed. China, on the other hand, has taken its first steps in the restoration of coal regions, and could profit from the new concepts while drawing on Germany's experience. The potentials of relevant strategies are investigated here through two case studies from Germany and China. Although there are significant differences in the post-mining development strategies of these two countries, it is clear that the green infrastructure concept can contribute significantly to a growth in ecosystem services. Four advantages of the green infrastructure concept are seen: First, it enables a systematic and highly objective assessment of mining impacts on the ecosystem. Second, the concept assists in the implementation of urban sustainability goals. Third, it is rooted in the local characteristics of landscapes. And finally, the green infrastructure concept seems to be highly compatible with tools of landscape and regional planning.
\end{abstract}

Keywords Post-mining development · Ecosystem services · Urban planning · Green space · China · Germany

\section{Introduction}

Mining is a highly dynamic process of intervention in landscapes, commonly accompanied by environmental damage and fundamental social and economic impacts. Such impacts not only persist during the period of active mining but also after reserves are exhausted and mines closed. Almost all mining regions around the world face a similar set of challenges in post-mining landscapes. Long-

Peter Wirth

p.wirth@ioer.de

1 Leibniz Institute of Ecological Urban and Regional Development (IOER), Weberplatz 1, 01217 Dresden, Germany

2 China University of Mining and Technology (CUMT), Daxue Road 1, Xuzhou 221116, China term mining leaves a legacy of considerable environmental degradation (Wende 2015; Chang and Yang 2015). The environmental impacts are usually accompanied by serious problems of urban and regional development such as economic decline, out-migration and demographic shrinkage (Wirth and Lintz 2007).

Over the last three decades, transformation processes in former mining regions have been investigated by researchers from many fields such as geography, sociology, engineering and planning (for an overview see Wirth et al. 2012). Descriptive and explanatory studies of post-mining areas have dealt with political, cultural, social and economic change. National programs have been set up in order to rehabilitate and economically transform affected areas, such as the restoration of former lignite, copper and uranium mining areas in the east of Germany (Lintz and Wirth 2009; Wirth et al. 2012; BMWi 2015). Considering the 
dynamic nature of such restoration processes, it is unsurprising that ecological and environmental planning tools have also been developed (Wende 2011, 2015).

The concept of green infrastructure (GI) is comparatively new. Arising in the USA in the 1990s (Firehock 2010), GI became popular in many countries at the beginning of the new millennium (Wright 2011). There is a wide consensus that GI can deliver significant environmental, social and economic benefits (Mell 2008). The GI concept encompasses all spatial levels. It focuses on connectivity of urban green space, aims at multi-functionality, forges a link to the spatial provision of ecosystem services and highlights the need for close collaboration between scientific, political and administrative actors (cf. Haase et al. 2014; Pauleit et al. 2011; Rouse and Bunster-Ossa 2013).

In 2013 the European Commission highlighted a new policy concept entitled 'Green Infrastructure (GI)' to close the gap between conventional land use and urban development on the one hand and sustainable urban development on the other. This GI concept tries to achieve a strategically planned network of valuable natural and seminatural areas, designed and managed to deliver a wide range of ecosystem services (ES) and to preserve biodiversity in rural and urban settings (European Union 2013). Thus, the concept follows the idea or Leitbild of improving ES and human well-being as well as promoting sustainable development in rural areas and cities.

In this article we suggest and show that the GI concept is also applicable to post-mining cities and regions. Clearly, mining activities have significant long-term impacts on the environment, on ecosystem services as well as biodiversity (Wirth and Lintz 2007; Cao 2007). All too often such impacts are tremendously damaging to ecosystems. Consequently, our leading research questions are: How can the idea of GI be applied to meet the specific requirements of mining regions and post-mining landscapes? And what are the strengths of the GI concept in relation to landscape restoration in coal-mining areas? We propose that the GI approach has a remarkable potential for the planning and management of former coal-mining areas burdened with a legacy of subsidence, coal gangue dumps, old industrial facilities and brownfields.

In the general post-mining context of China and Germany, this paper aims to develop ways of combining GI with specific concepts of post-mining landscapes by examining two different regional settings. Coal is one of the most important sources of energy in China, and in Germany will remain an important fuel until the completion of the country's Energiewende towards renewables. Germany has already gained some experience in both ecological restoration and green city reconstruction using GI strategies (see WBGU 2016; BMUB 2017). While this application of GI is still at an early stage, these initial experiences could be of significant benefit for China and other regions around the world. In the following we investigate coal-mining cities in China and Germany, capturing temporal-spatial differences in scales and landscape structures with the aim of revealing GI strategies and laws to upgrade urban ecosystems. A particular focus is on the protection and enhancement of ecosystem services using the GI concept.

The article is subdivided into five sections. Following this introduction, Sect. 2 considers the state of research on the concepts of post-mining and GI. In Sect. 3, two case studies from China and Germany are presented to illustrate possible applications of GI in post-mining areas. In Sect. 4, these two case studies are appraised, compared and evaluated against the background of the conceptual framework of Sect. 2 in order to reveal opportunities and limits of the different practical approaches. In the final section we derive some conclusions from the findings, which should be applicable to other regional and international contexts.

\section{General considerations of post-mining development, GI and ES}

\subsection{Connections between post-mining regions and the GI concept}

One legacy of mining operations in China is a large number of post-mining landscapes, generally situated in urban areas that thrived during the country's period of industrialization. Clearly, such landscapes are associated with a number of negative impacts on the environment as well as living conditions (Chen et al. 2010; Luo and Chen 2011; Chang and Yang 2015; Ma and Hu 2015). Comprehensive land reclamation planning for mining areas and mine rehabilitation are still at an exploratory level and lack a theoretical foundation, while research on ecological restoration and rehabilitation remains at a qualitative, descriptive stage. In particular, the country requires a stable, socio-economically and environmentally coordinated regulatory framework for the coal sector, one that encompasses the question of mine-closure (Cao 2017). The process of implementing land restoration has been hindered by problems such as inadequate management, a lack of feedback and monitoring, and conflict with the various aims of urban development (Chang et al. 2011).

It is widely agreed that the successful transformation of mining cities and regions can only be achieved through comprehensive environmental and the socio-economic change. Damage to the landscape through mining activities should be remedied and compensated through a series of measures which are embedded in an overall strategy 
(Hennek and Unselt 2002; Wende et al. 2009; Wende 2015; Chang and Yang 2015). Ideally, these need to be developed and conceptualized in detail before the start of mining activities, including an assessment of ES (Syrbe 2015). In Germany there are several examples of successful mining transformations and the re-use of post-mining landscapes, realized through a combination of environmental restoration and socio-economic redevelopment (Ache 2000; Wissen 2001; Wirth et al. 2012; Harfst and Wirth 2011; Lockie et al. 2009). Against this background, the GI concept has a number of useful features (see Hansen and Pauleit 2014, p. 517), which could assist cities and regions in the transition process from mining to post-mining:

- Integration: urban green is viewed as a form of infrastructure, which can be integrated with other urban infrastructures in terms of physical and functional relations;

- Multifunctionality: GI planning encompasses the ecological, social, economic, abiotic/biotic and cultural functions of green spaces;

- Connectivity: GI planning considers physical and functional connections between green spaces at different scales;

- Multi-scale approach: GI can be applied to initiatives at different scales, from individual parcels to the community, regional, and state level;

- Multi-object approach: GI includes all kinds of green and blue space, natural and semi-natural areas, water bodies, parks and gardens, etc.

This experience can be of great assistance to China, which is currently confronted with problems similar to those of Europe some 30-40 years ago. The reprocessing and transfer of such experience could also generate ideas and opportunities for the development of corresponding geographical theory, ecological and environmental planning methodology and technology for wider use. Hence, Germany's experience should not be merely transferred to China but used to enhance methodology and to improve implementation in both countries (Müller et al. 2005).

Examination of the overall state of the art reveals a significant research gap on how to integrate the concepts of post-mining and GI to improve citizens' quality of life in affected cities.

\subsection{Potentials of ES against the background of post- mining development}

Ecosystems as well as all kinds of vegetated areas (here called green spaces) provide a wide range of ecosystem services (ES) to cities. The benefits for urban residents largely depend on the quality of these urban green spaces. The concept of ES is now commonly employed in the environmental debate on the development of urban nature conservation strategies. The upgrading of green spaces highlights urban ES, particularly regarding their benefits for health and recreation. Urban green spaces are found in a broad variety of types, ranging from high maintenance urban parks to natural areas and buffer spaces between facilities of technical infrastructure and other land uses. Diverse benefits are generated by urban green spaces, reflecting the heterogeneity of such spaces (Panduro and Veie 2013). The location, vertical structure, composition and configuration of urban green spaces all influence the ecological qualities and services (Grunewald et al. 2017).

Whereas the ES concept is commonly employed in urban and regional landscape planning (e.g. Grunewald and Bastian 2015; Maraja et al. 2016; Panduro and Veie 2013), there is less experience of ES in relation to mining cities and post-mining development. In general, post-mining regions are characterized by multiple forms of environmental damage (such as landscape degradation, land instability, landslides, soil erosion), by pollution of the air, soil and water as well as by a general lack of green spaces (Wirth et al. 2012). In view of such problems, long-term mining activities (in many cases 100 years and more) clearly hamper urban development. Yet after the cessation of mining, the damaged areas can be interpreted as a potential for urban development, for the re-cultivation of new green spaces easily accessible by local residents and which can serve as attractors for the urban future. One attempt in Europe to adapt the ES concept to post-mining areas is the study by Larondelle and Haase (2012). The authors quantify several ecosystem services in a large lignite mining area in Germany in order to assess the impacts of mining on the landscape and to construct future development perspectives.

In the following, we discuss the physical legacy of mining and its ES potentials, specifically in the case of cities affected by the repercussions of hard coal-mining, a topic of considerable relevance in China today. The Common International Classification of Ecosystem Services (Haines-Young 2013) defines three basic classes of $\mathrm{ES}$, which shall be used here to structure the current section. These are: regulation and maintenance, i.e. the mediation of flows and of climate; cultural, i.e. physical, intellectual and spiritual services as well as the interaction with nature; and provisioning, e.g. the supply of food or water.

Firstly, regulation and maintenance services contribute significantly to environmental quality in cities. Depending on the environmental situation, the most important regulation services are climate and water regulation, carbon sequestration, as well as pest and erosion control. 
Maintenance services support the lifecycles of biota as well as protecting the local and regional gene pools.

The main functional element of GI is to ensure a wellconnected habitat network, permeable to several organisms. Brownfields, former mining sites as well as abandoned landscape elements connected to mining activities such as dumps, mine railways, conveyor and pipeline systems are hugely important as potential sites for the establishment of future green networks. Though often small in size, such sites can provide important pathways or at least stepping-stones for wildlife and gene exchange if secured for this purpose and maintained accordingly. Therefore, if a basic design for GI is drawn up for each mining city, this can help to guide post-mining planning (Grunewald et al. 2017).

Urban areas often suffer from so-called urban heat islands (UHIs), characterized by aridity, heat and lower wind strengths compared to the rural surroundings (Arnfield 2003). Typical physical legacies of mining activities such as wet areas affected by subsidence or dry, wind-exposed dumps can help to mitigate the impact of UHIs if such sites are made safe, free of pollution and planted with specific forms of vegetation to create valuable habitats. Climateregulating ecosystem services are becoming ever more important to help counter the impact of climate change. In particular, water-logged ground as well as water bodies, which frequently emerge in former mining areas, can mitigate strong temperature differences or serve as pathways for the inflow of cold, fresh air from rural to urban areas. Also, the shift in airflows caused by dumps and hollows could boost air movement and thus balance the UHI.

Green spaces help to regulate the urban water cycle. The main elements of this cycle, namely evapotranspiration, surface runoff, infiltration, groundwater-recharge, subsurface flow, spring discharge and stream flow, provide the ecosystem services of water regeneration and purification without the need for large-scale technical investments. Yet building activities and an expanding transport system increase the extent of sealed surfaces, reducing possible infiltration and space for vegetation. This hinders groundwater recharge, affects the supply of freshwater and increases the amount and speed of surface runoff, thereby raising the likelihood of flooding and hence necessitating additional physical safeguards (Weller et al. 2012). One possible solution is the so-called 'sponge city' concept, developed in China, whereby rainwater is absorbed, stored and released in the vegetation, soil and substrate of a city much like a sponge (Wang et al. 2015). A large problem is that mining cities show an unstable flow system that occasionally may even reverse direction, so that drainage systems can break down. Therefore, well-adjusted groundwater and runoff models must be applied when designing the surface water system in such areas.
Secondly, cultural values are primarily connected with the accessibility of green spaces. In their study of the situation in Germany, Maraja et al. (2016) have identified recreation and tourism, nature experience, aesthetic values, the sense of place and local identity, places for social relations as well as educational, spiritual and religious values as the most important cultural ES. Abandoned mines and areas damaged by mining activities are ideally suited for upgrading as green spaces precisely because their specific problems preclude the development of housing or new industries. Hence, the general aim is to make these areas safe and accessible to the local population.

When maintained in a good state, urban green spaces enable a close experience of nature as well as providing places for relaxation or aesthetic enjoyment, recreation and sporting activities. In so doing, they contribute to citizens' psychological and physical regeneration. In a study of 30 Chinese cities, Smyth et al. (2008) found that residents with greater access to urban parks experienced higher levels of well-being. Similar results have been found for Germany (Krekel et al. 2016). In particular, urban grassland, forest and water bodies have a positive impact on mental and physical health.

Thirdly, provisioning services are often connected with the production of food such as urban agriculture, fishing, forestry and gardening. Such activities, however, make up only a small part of the supply of resources required by local residents. The more valuable part of urban provisioning services consists of resources supplied by ecosystems such as water for drinking and production, raw materials (fibers, timber) as well as renewable energy (hydropower, biogas, firewood, etc.). This latter resource is of increasing importance, especially in Germany. Familiar ecosystem products that are becoming more and more popular in cities include honey and fruits from meadows with scattered trees. These examples show how the sustainable use of ES can be combined with the conservation of valuable green spaces if such utilization is not oriented towards the optimization of only one kind of product. Mining cities often encompass areas that are not suited to the development of housing or industrial activities; alternatively, they have the potential to generate renewable forms of energy. In cases where former mining areas cannot be used for food production, they can be redeveloped with short rotation coppices or other kinds of plantation to provide renewable raw materials or energy crops. Biofuel crops can also be planted on polluted soils if the problem of residues and emissions can be resolved. The introduction of such biofuel crops can serve to establish a new industrial profile, and can be combined with other forms of renewable sources of energy such as solar power, wind power as well as hydropower or storage. Another development option particularly applicable to areas 
afflicted by post-mining subsidence is to establish so-called paludicultures (Wichtmann et al. 2016). This is the cultivation of wetlands and shallow lakes with adapted plants such as reeds and willows.

In summary, the examples above show how the physical legacy of mining activities can be upgraded, redeveloped and used in a way that simultaneously generates and maintains various ecosystem services such as cultural experience, climate regulation and energy production. In this way local residents are able to draw multiple benefits from a single site, thereby improving the quality of life in former mining cities.

\section{Case studies}

In order to analyze the supporting role which GI could play in the transformation of coal-mining areas, two contrasting case study regions were chosen: Zwickau-Lugau-Oelsnitz (Germany) and Xuzhou (China). These are suitable for analysis because: (1) Several research projects have already been conducted in these regions, producing a great deal of information; (2) the current authors were involved in research and planning tasks in these regions; and (3) the regions have already made some progress in restoration, allowing for a thorough assessment of the application of GI.

The two research projects underpinning this article were carried out independently of one another in Germany and China. Research by the German team started in 2009 with the INTERREG IV-B project Re-Source (2009-2012), dealing with ecological restoration and post-industrial strategy development (Harfst and Wirth 2012). Further data collection in the Zwickau-Lugau-Oelsnitz region was undertaken in 2015 by one of the authors as an external expert to the Saxon Horticultural Show in Oelsnitz. Basic data for the German case study was drawn from the analysis of relevant planning documents regarding the postmining period from 1998 to 2017, statistics on the socioeconomic development of the Zwickau-Lugau-Oelsnitz area, semi-structured interviews as well as three group discussions with regional stakeholders $(2010,2012,2015)$. The basic dataset was updated in 2017 to allow comparison with the data from China.

Initial research into the Chinese region was undertaken in the project "Ecological Restoration Planning of Mining Subsidence Areas in Xuzhou", supported by the Government Xuzhou (2008-2010). Further data was gathered by a "Study on reutilization of industrial wasteland in mining towns from the perspective of urban and rural overall planning”, which ran from 2012 to 2015 (Feng et al. 2016). In 2016, the committee of Lake Pan'an launched a monitoring project "Protection and Restoration of Pan'an-lake wetland park", compiled by the Jiangsu Academy of Forestry and the company Nanjing Puhou Ecological Technology Ltd. The Chinese authors of the current paper were involved in the project, which intends to establish a daily monitoring system for the wetland park which includes specific measures such as a wetland ecological monitoring project, publicity and education, wetland drainage, water quality restoration, and wetland management.

The German and China research teams cooperate since 2012, beginning with the project "Partners for Sustainability: Post-carbon Energy Concepts for Mining Areas", funded by the Robert Bosch Foundation. When it became clear that both countries were facing similar developmental problems, the idea was born to pursue a comparative approach. The joint efforts gained momentum in the framework of the conference "Land Reclamation in Ecological Fragile Areas" held in October 2017 in Xian/China. By harmonizing the research methods, updating data and consolidating information regarding the areas under investigation, the two case studies presented here evolved to follow approximately the same design. In order to describe changes to ES in the process of mine land restoration, we use the ES impact method originally developed by Bastian et al. (2013) and Lupp et al. (2015) for the comparison of different scenarios. Under this method, we select the most variable and important ecosystem services impacted by the given landscape changes and make a qualitative comparison of the differences in ES supply between the two case studies areas (rather than considering different scenarios in one area).

\subsection{German case: the Zwickau-Lugau-Oelsnitz coal-mining district}

\subsubsection{Geographical features and mining history}

Located in the state of Saxony (Germany), the former mining district of Zwickau-Lugau-Oelsnitz covers an area of $273 \mathrm{~km}^{2}$. In 2015 the population was 153,699. The district encompasses the city of Zwickau, serving as a regional hub, as well as eight surrounding suburban or rural communities, namely Reinsdorf, Mülsen, Lichtenstein, Hohndorf, Gersdorf, Lugau, Oelsnitz/Erzgebirge and Hartenstein (Fig. 1). Situated in the Chemnitz-Zwickau agglomeration, the local population density is rather high at 563 inhabitants per $\mathrm{km}^{2}$ (the national figure is 230 per $\mathrm{km}^{2}$ ). Nevertheless, the population has declined in all municipalities over recent decades. Specifically, the area has lost around 30\% of its inhabitants since 1990.

Zwickau is the biggest city of the former mining district with a population of 91123 (2015). It is the region's administrative, industrial and cultural center, whose reach extends far beyond the Zwickau-Lugau-Oelsnitz area. The 


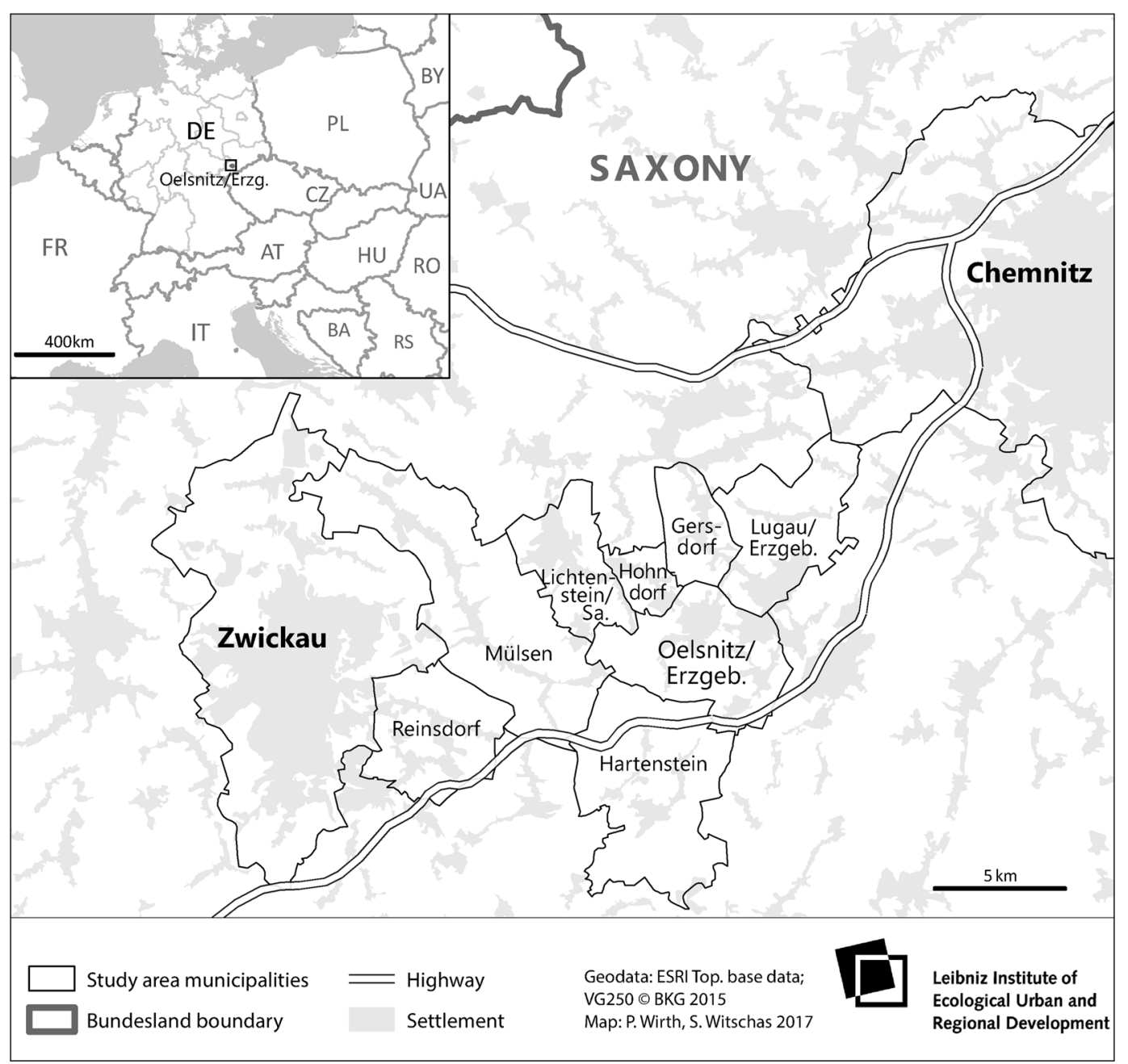

Fig. 1 Study area of Zwickau-Lugau-Oelsnitz

city is the capital of the administrative district (Landkreis) of Zwickau and accommodates various regionally important cultural facilities such as museums and theatres as well as a university of applied sciences (for more information see Harfst and Wirth 2012).

The entire Zwickau-Lugau-Oelsnitz area is part of the old industrial heartland of southern Saxony, stretching from Zwickau in the west to Chemnitz in the east. This area underwent rapid and intensive industrialization from the 1850 s onwards, making it a central European hub of various industries such as textile production, manufacturing and coal-mining. While the region retained its industrial character under the socialist economic system of the German Democratic Republic (GDR) until 1989, coal production was already phased out in the 1970s due to its unprofitability.

\subsubsection{Impacts of mining}

The first evidence of hard coal mining in the Zwickau region dates back to 1348 (Hoth et al. 2009). During the main period of industrial mining from ca. 1850 to 1978 , some 207 million tons of coal was extracted from the Zwickau coalfield, while the Lugau-Oelsnitz field produced 142 million tons between 1844 and 1971. Although mining activities were entirely underground, this work had significant environmental impacts on the surface. Postmining development is still dealing with three main legacies from mining activities: firstly, the dumps of gangue (i. e. worthless rock); secondly, a number of subsidence areas; and thirdly, the numerous brownfields (Harfst and Wirth 2012).

One of today's greatest challenges for the region is the incomplete rehabilitation of former mining sites after their closure in the 1970s. For example, dumps were only partly afforested or simply abandoned to spontaneous vegetation. Today the region contains 80 dumps, the smallest less than 
1 hectare in size and the biggest extending 26 hectares. In total, these cover 336 hectares of land (Felix et al. 2009). After the cessation of mining, most shafts were decommissioned and sealed. After many years of physical neglect, areas of subsidence can now be found in all places where underground mining was conducted. Clearly, these are associated with various long-term problems. Surface subsidence caused by the remaining unstable mining galleries has reached a maximum of 16 meters in Zwickau (Hoth et al. 2009) and $17 \mathrm{~m}$ in Oelsnitz (Berrios and Kolitsch 2001). Furthermore, groundwater levels are rising and there is a danger of toxic washout. In addition, subsidence causes persistent and recurring damage to buildings and infrastructure, and is a major obstacle to urban and infrastructure planning and development in the region.

\subsubsection{Ecosystem potentials and services of post-mining areas}

The potentials of coal-mining sites in the Zwickau-LugauOelsnitz region are mainly determined by the existence of areas of subsidence, coal gangue heaps as well as brownfields. In previous years, the mining heaps, which are spread over the whole area, have been viewed as offering the greatest potential. Despite their incomplete rehabilitation (see above), such heaps are used for recreation and sporting activities such as strolling, dog-walking, jogging and mountain biking (1) ( $N B$ : encircled numbers refer to Table 1). In Lugau a motocross track has been built on top of a mining heap (1). In addition to these cultural services, biomass production (firewood) is likely to become more important over the next few years due to Germany's nationwide transition to renewable energies (2). In the city of Zwickau, mining heaps also help to regulate the urban climate (3) by fostering an inflow of fresh air and buffering the summer heat. Furthermore, many of these heaps provide dry habitats seldom found in the surrounding cultural landscape for plants and animals (4).

In contrast, subsidence is predominantly seen as a problem for urban development in the region. In Zwickau, subsidence affects the districts of Bockwa and Schedewitz, where built-up areas are at permanent risk of flooding by groundwater. However, subsidence can also bring new potentials: The steepening of the course of the river Mulde enabled its use for canoeing (5) (Hoth et al. 2009). As a precaution, the groundwater level has been lowered by pumping stations. Consequently, the subsidence areas are generally viewed as a burden rather than a potential for future development (6). Regarding brownfields, which encompass large areas of shaft towers and other surface mining facilities, disused railway tracks and terminals, coking plants, power stations, etc., there are two contrasting trends: Many areas have been reused for reindustrialization projects in the 40 years since the end of mining, while (as will be shown in the next section) others form a basis for GI. These new green spaces include former infrastructural elements such as mining railways, roads,

Table 1 Changes to ecosystem services when transforming mining legacies into green spaces (case of Zwickau-Lugau-Oelsnitz)

\begin{tabular}{|c|c|c|c|}
\hline Mining legacies & Areas of subsidence & Coal gangue heaps & Brownfields \\
\hline $\begin{array}{l}\text { Restructuring } \\
\text { measures }\end{array}$ & $\begin{array}{l}\text { Deconstruction, wetland use, lake } \\
\text { areas }\end{array}$ & $\begin{array}{l}\text { Stabilization, covering, } \\
\text { planting }\end{array}$ & $\begin{array}{l}\text { Deconstruction, surface unsealing, } \\
\text { decontamination }\end{array}$ \\
\hline \multicolumn{4}{|l|}{ Regulating ES } \\
\hline $\begin{array}{l}\text { Local climate } \\
\text { regulation }\end{array}$ & 仓 (s. Sect. 2.2) & 仓 (3) & - \\
\hline Carbon sequestration & - & is (8) & - \\
\hline Water regulation & ת (6) (s. Sect. 2.2) & - & $\hat{\imath}$ (s. Sect. 2.2) \\
\hline \multicolumn{4}{|l|}{ Cultural ES } \\
\hline $\begin{array}{l}\text { Opportunities for } \\
\text { sports }\end{array}$ & i (5) (aquatics) & 仓 (1) & 仓 (new paths) \\
\hline Habitat and species & پ (s. Sect. 2.2) & i (4) & i $(7)$ \\
\hline $\begin{array}{l}\text { Heritage/sense of } \\
\text { place }\end{array}$ & - & 仓 (8) & 仓 (9) \\
\hline Recreation & थ (8) & ษ (8) & i (8) (9) \\
\hline \multicolumn{4}{|l|}{ Provisioning ES } \\
\hline Renewable energy & 凹 (s. Sect. 2.2) & 仓 (2) & - \\
\hline Food: (fruits/honey) & 仓 (s. Sect. 2.2) & ษ (s. Sect. 2.2) & 仓 (9) \\
\hline
\end{tabular}

Symbols: (1) encircled numbers refer to examples in the text, $\uparrow$ service increasing, $\Omega$ service decreasing, - Service unimportant or non-uniform change 


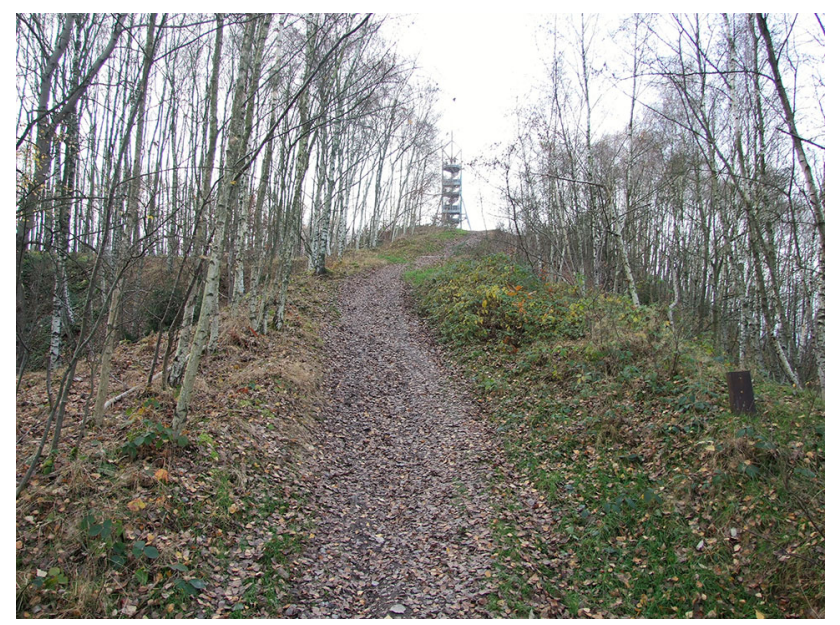

Fig. 2 Hiking trail and viewing tower on the former coal-mining dump 'Deutschlandschachthalde' in Oelsnitz (photo: Bieberstein/ IOER)

pipelines and conveyor systems. Such elongated areas are preferred links for biotope networking (7).

Amongst the manifold activities, some projects can be highlighted. For example, Oelsnitz municipality developed a local recreation area at the region's biggest dump, namely the 'Deutschlandschachthalde' (Fig. 2). A viewing tower was erected on the mainly afforested heap in 2000 , serving as the main attraction on a hiking trail that connects several key sites of former mining activities in the town and its surroundings (8).

The most ambitious post-mining project in the investigated region has been the Saxon Horticultural Show of 2015 , located around the former coal loading station in Oelsnitz. The project encompassed the design of a modern exhibition area covering 15 hectares. The concept included green spaces for trees and flowers as well as recreation sites such as a skating course and a graduation tower (for the production of salt through evaporation). Over a period of 6 months, more than 400000 people visited the exhibition. Subsequently, the area has been used as a municipal park (9).

\subsection{Chinese case: Xuzhou}

\subsubsection{Urban development and coal-mining activities}

Xuzhou City is located in the northwest of Jiangsu province, China (Fig. 3). With five urban districts and five counties, ${ }^{1}$ it covers a total area of $11258 \mathrm{~km}^{2}$ and has 10.3 million residents, among them 3.3 million in the urban center (2016). Xuzhou, the first city to be founded in Jiangsu province, is one of the nine ancient cities in China

\footnotetext{
1 The administrative level of "county" is equal to "urban district" in prefecture-level cities in China.
}

and enjoys a rich history stretching back nearly 2600 years. Coal-mining has been carried out for 900 years in Xuzhou. The setting up of the Liguo Iron and Coal Mining Bureau in 1882 marked the beginning of the large-scale exploitation and utilization of coal, as well as launching modern industrial processes in Xuzhou (Chang et al. 2011).

Following the foundation of the People's Republic of China in 1949, more than one thousand state-owned enterprises in the fields of coal-mining, machine manufacture, chemicals, building materials and metallurgy were established in Xuzhou. All of these were strongly dependent on local coal resources. Enjoying the only fuel resource in Jiangsu province, the output of heavy industry in Xuzhou accounted for a quarter of the entire output of Jiangsu province at the peak period. According to the Master Plan of Xuzhou City for 1979 , priority was to be given to the development of coal resources and electric power as well as the creation of a transport hub and regional business center (Shen et al. 2012). At the end of the twentieth century, the old industrial system was greatly impacted by shifting structures of power generation, accompanied by the rapid development of other sectors such as manufacturing, commerce and services. In line with central governmental policy, the provincial government began to support the process of urban transformation. A central document on the "Revitalization of the Old Industrial Base of Xuzhou" stressed the development of manufacturing, tourism and services as new pillars of the economy (People's Government of Jiangsu Province 2008). Exploiting the historic, cultural and ecological background, ecological tourism became a development goal in the 2007 Master Plan of Xuzhou City.

\subsubsection{Impacts of mining}

Centuries of coal-mining activities have brought considerable economic benefits to Xuzhou. At the same time the physical legacy of mining has generated a number of obstacles to urban development. The most important of these are areas of subsidence that negatively impact the urban ecological environment (Chang and Koetter 2005; Chang and Feng 2008). According to data from 2012, 16133 ha of land susceptible to subsidence from mining activities could be located in the five urban districts of Xuzhou; $72 \%$ of these areas had not been upgraded and remained subject to subsidence. Most sites are located in fringe areas where the ecological and social environments are highly sensitive. The areas affected by subsidence form a semicircle to the north of the main urban area, restricting the city's development in a swathe of land from the northwest to the north-east. At other sites, ecosystems have been disturbed, resulting in the isolation of valuable green spaces. The areas of subsidence are mainly located in 


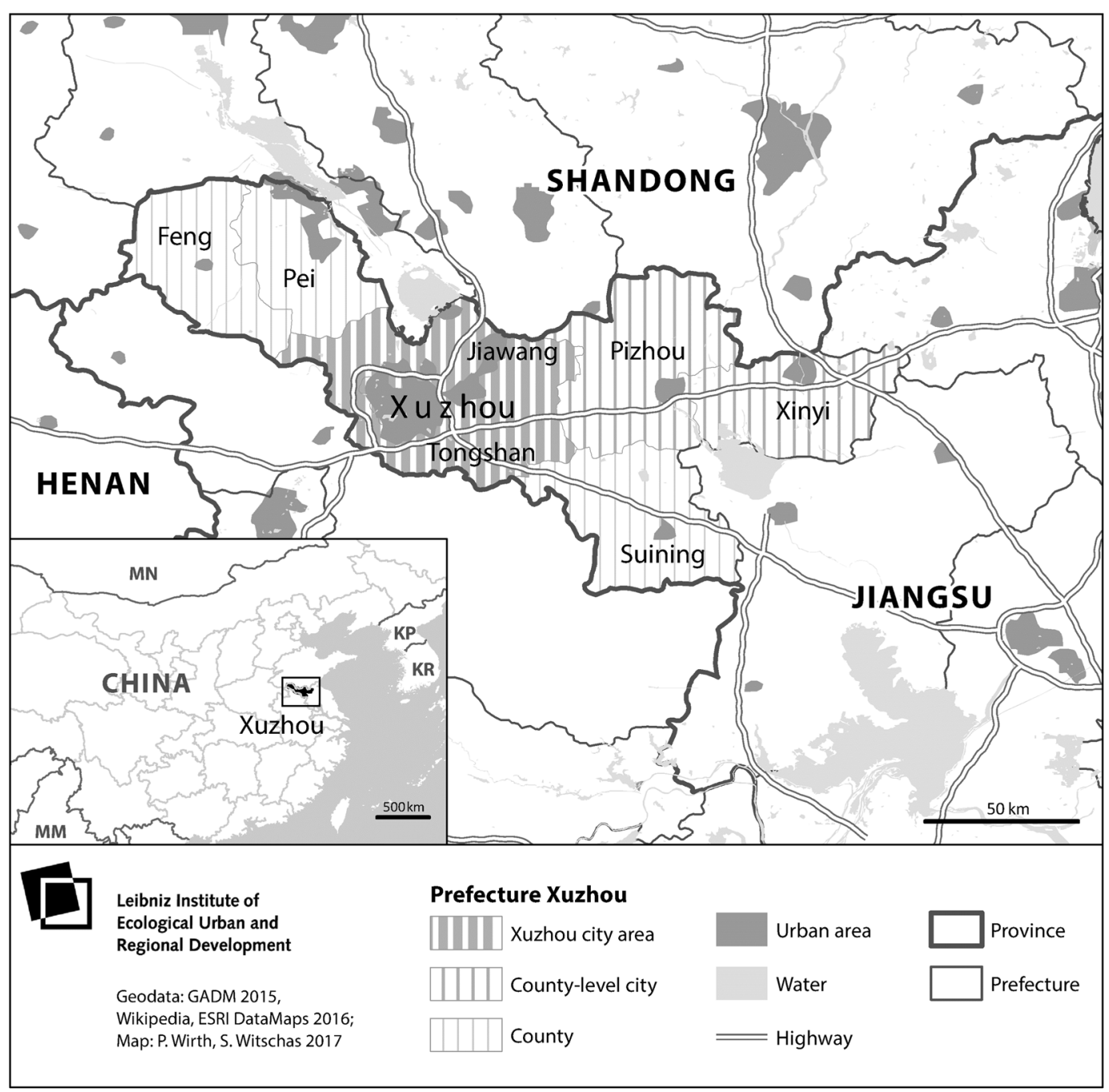

Fig. 3 Study area of Xuzhou

Tongshan district and Jiawang district in Xuzhou urban area (Feng et al. 2016).

\subsubsection{Ecosystem potentials and services of post-mining areas}

Although subsidence hampers urban expansion, affected areas constitute an important resource for the ecological development of Xuzhou (see also the encircled numbers, which refer to Table 2). Due to the long-term abandonment of such sites and lack of human disturbance, local ecosystems are in a process of self-recovery and natural succession, leading to the formation of areas with rich ecological potential and providing space for endangered species (Chang et al. 2011). In fact, these lands have never been "abandoned", but rather help to form an integrated ecological network (Feng et al. 2016). Areas of subsidence, in particular the surface water system (1), have a special significance for the maintenance and control of the ecosystem network when restoration and reconstruction have been implemented in some key patches and core areas. After restoration, post-mining lands can provide important ecosystem services, namely:

(1) Agricultural use, which is one of the most typical recovery goals for post-mining lands, provides the majority of provisioning services. The transformation of post-mining lands into agricultural and forested land can provide food, wood and other natural resources for residents.

(2) The establishment of wildlife areas and nature reserves in post-mining landscapes helps to foster biodiversity (2).

(3) After restoration, post-mining landscapes can have a positive impact on the regional ecological environment through improved climate and air quality (3), carbon sequestration and storage (4), the prevention 
of soil erosion, improved soil fertility by natural methods, higher levels of pollination (5), etc.

(4) Abandoned mines close to urban areas can be used as parks, stadiums, golf courses and fishing zones, thereby boosting the range of community and cultural services.

(5) Due to the high sulphur content, vegetation will generally not grow on the remains of coal gangue heaps. Instead, the heaps are used to provide underground backfill to prevent subsidence in mining areas, as substitute material for making bricks or concrete and as fuel for power plants. Renewable energy can be generated by new-constructed solar power plants within mining lands, particularly in areas of shallow subsidence (6).

A typical example of the implementation of this program is the construction of Pan'an Wetland Park (Fig. 4). Created on vast areas affected by subsidence from coalmining activities, the park has a total area of $16 \mathrm{~km}^{2}$. In order to implement the restoration work in the Pan 'an lake area, the city established a construction model including basic farmland management (7), the reclamation of subsidence areas, ecological restoration and landscape development in wetlands. An afforestation and restoration project was launched in 2011. After 2 years of restoration work, an area of $4.3 \mathrm{~km}^{2}$ was reclaimed to form a continuous lake and water catchment area. More than 100 kinds of trees, 200 varieties of shrubs and 300 varieties of aquatic plants (8) were planted (Zhang 2015). A huge wetland landscape was created to meet the demands of tourism. By the end of 2015, Pan'an Wetland Park had attracted more than 3.6 million visitors (9). Its construction demonstrated how a barrier to development can be transformed into a regional attraction. A series of large public events such as an international music festival, a crosscountry run (10) as well as film and television activities has greatly enriched citizens' lives (11) (Wang et al. 2016).

From a scientific perspective, this ecological restoration plan for areas afflicted by post-mining subsidence in Xuzhou is realized through a combination of environmental restoration, urban sprawl control, village relocation and new rural development (Lin et al. 2009; Chang et al. 2011). In the meantime, a cooperative platform has been established for various interest groups such as local residents, scholars, policymakers, investors as well as operators in order to increase their awareness of social, economic and ecological factors.

\section{Discussion}

Here we return to the research questions: How can the idea of GI be applied to meet the specific requirements of mining regions and post-mining landscapes? And what are the strengths of the GI concept in relation to landscape restoration in coal mining areas? In formulating answers, we first have to remember that it was not the explicit goal of actors in the investigated cases in Germany and China to create what we call here 'green infrastructure'. First and foremost, the motivation of local actors was to overcome the negative environmental impacts of coal-mining, to raise the living conditions of inhabitants, and to remove obstacles to urban development. The realized measures were based on concepts that combined clean-up activities, greening and improved wellbeing. Hence, we have to consider the effects of the tested strategies and determine how they are related to the planning concept of GI.

\subsection{Comparing the two cases}

Firstly, we can point to a range of similarities, which are mainly related to the nature of hard coal-mining and its impacts the landscapes and ecosystems, as well as societal needs in the mining regions. Clearly, the character of landscapes has been substantially transformed by mining activities, whether through the creation of dumps or widespread subsidence. Furthermore, ecosystems have been negatively impacted through soil and water pollution as well as damaged wildlife habitats. Without rehabilitation measures, many affected areas are unable to play a role in urban and regional development concepts and programs. Even after rehabilitation, many planning restrictions remain for urban development, for example due to large underground cavities, toxic contamination of soils and soil erosion. Yet such restrictions do not entirely prevent the utilization of ES in such areas or their integration into urban and regional concepts. As explained in Sect. 3, postmining sites can help regulate the local climate, they can be used for the production of raw materials and bio-energy, for recreation or to foster biodiversity. Clearly, all classes of ES as described in Sect. 2 (provisioning, regulation and maintenance, cultural) are relevant to the case study areas. Comparing Tables 1 and 2, we note in particular the similarity in ES changes regarding water regulation and food production, i.e. although water regulation remains a problem due to the occurrence of subsidence in both countries, it can be enhanced elsewhere; further, food provision can generally be enhanced in post-mining landscapes.

From a societal perspective, we can observe a paradigm shift. During the period of industrialization, the coal-mining areas were hotbeds of innovation, technological 
Table 2 Changes to ecosystem services when transforming mining legacies into green spaces (case of Xuzhou)

\begin{tabular}{|c|c|c|c|}
\hline Mining legacies & Areas of subsidence & Coal gangue heaps & Brownfields \\
\hline $\begin{array}{l}\text { Restructuring } \\
\text { measures }\end{array}$ & $\begin{array}{l}\text { Deconstruction, wetland use, lake } \\
\text { areas }\end{array}$ & $\begin{array}{l}\text { Backfill, industrial reuse of the } \\
\text { material }\end{array}$ & $\begin{array}{l}\text { Deconstruction, surface unsealing, } \\
\text { decontamination }\end{array}$ \\
\hline \multicolumn{4}{|l|}{ Regulating ES } \\
\hline $\begin{array}{l}\text { Local climate } \\
\text { regulation }\end{array}$ & i (3) & - & 仓 (3) \\
\hline Carbon sequestration & i) (4) (8) & - & i (4) \\
\hline Water regulation & ᄀ (1) & - & $\hat{\uplus}$ (s. Sect. 2.2) \\
\hline Pollination & i (5) & - & i (5) \\
\hline \multicolumn{4}{|l|}{ Cultural ES } \\
\hline $\begin{array}{l}\text { Opportunities for } \\
\text { sports }\end{array}$ & ษ (10) & - & 仓 (10) \\
\hline Habitat and species & $\sqrt{2}$ (2) \ (8) & - & i (8) \\
\hline $\begin{array}{l}\text { Heritage/ } \\
\text { identification }\end{array}$ & 仓 (11) & - & $\hat{\imath}$ (s. Sect. 2.2) \\
\hline Recreation & i (9) (10) (11) & - & 仓 (9) \\
\hline \multicolumn{4}{|l|}{ Provisioning ES } \\
\hline Food (crops, fish) & i (7) & - & i (7) \\
\hline Raw materials & - & 仓 (6) & - \\
\hline Energy & i (6) & 仓ि (6) & - \\
\hline
\end{tabular}

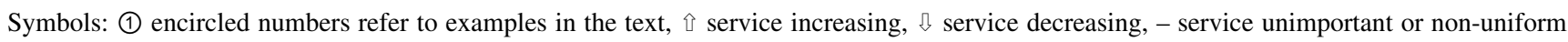
change

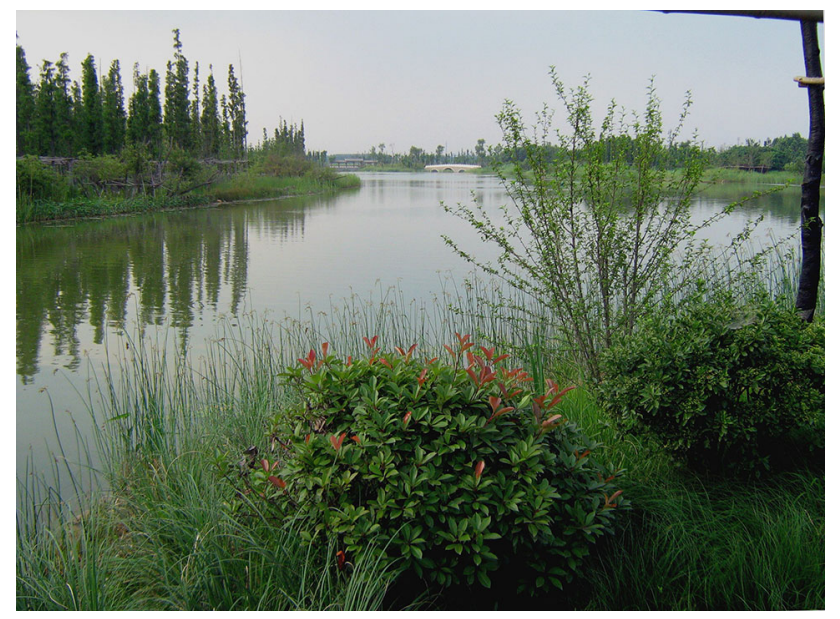

Fig. 4 Pan'an Wetland Park in Xuzhou/China, created through the restoration of post-mining areas (photo: Syrbe/IOER)

progress and economic vitality, irrespective of the political and economic system. Economically, the cities benefited greatly from the extracting industries, and their populations were mostly increasing. Ecological damage was ignored for a long period or dismissed as a minor concern. In the post-industrial period, there is great appreciation of the problems left by mining, specifically the environmental damage and the impacts on the future development of cities. The question arises of how best to deal with this physical legacy, often seen as a burden on urban development. In both case studies we can observe a change in urban and regional development strategies, most obviously in the case of Xuzhou City, whose primary function has shifted from a 'resource city' to a place of historic, cultural and ecological importance. This is an excellent condition for applying the GI approach.

The differences in handling the physical legacy of mining in the presented cases have a number of causes. Specifically, we can point to the disparate dimensions and technologies of mining, as well as local characteristics such as the location of mining facilities in relation to built-up areas. In the Chinese case, areas of subsidence play a decisive role in discussions around mine closure and restoration. Such areas form a semicircle on the outskirts of the settlement area. This is the reason why wetland areas have come to dominate post-mining planning in Xuzhou. In contrast, subsidence areas from mining are a considerable burden in Zwickau-Lugau-Oelsnitz, where some built-up areas are at permanent risk of flooding by groundwater. Instead, the main focus of urban planning in the German case is on the manifold mining dumps. Spread over the whole of the former mining district in an irregular pattern, they can potentially be transformed into sites for recreation, sports as well as new habitats.

In spite of these differences in the physical character of the former mining sites, their ecological potentials have been identified by urban and regional planners for some years. Today, we note that many of the implemented 
projects in the presented case studies fit very well with the new perspective of GI. The advantage of GI seems to be in the systematic conceptualization of ES to include potentials for urban and regional development. Of course, the cases of China and German present contrasting political strategies and social demands (cf. Table 1 and 2). For instance, the demand for renewable energy and aquatic sports is higher in Germany, while the demand for some provisioning services (fish, honey, wood) and, in particular, space for specific cultural activities is more pronounced in China.

\subsection{Opportunities of the GI concept}

Under quite different initial conditions, our two case studies in China and Germany show the value of the physical legacy of mining if sites are developed into functional green spaces to supply basic services to residents. Therefore, the GI concept opens up the possibility of systematically developing not only the technical but also positive ecological factors in a city, particularly under consideration of spatial connectivity. Due to its integrated perspective, the GI approach encourages the assessment and consideration of a multitude of ecosystem services as benchmarks for livability and sustainability, whose improvement will foster the successful development of mining cities. Although the character of the affected cities and regions in our examples were negatively impacted by mining activities, post-mining landscapes could subsequently be upgraded and living conditions improved. In the observed cases, however, the planning and implementation of projects were in part intuitive, depending at each step on the priorities of local and state policies. Since a more comprehensive planning approach is demanded politically (if not yet legally-anchored in all cases), the way to this from an ecological point of view can be the GI concept.

Adoption of the GI concept will encourage more systematic exploitation of ecosystem potentials in post-mining areas. Instead of focusing on just a single function (such as land development) or ecosystem service, a wider consideration of the potentials of the diverse pattern of green spaces typical of post-mining landscapes can ensure delivery of a greater range of services to the local population. Both Tables 1 and 2 show predominant improvements in the ES of the common types of mining sites and ecosystems. In order to develop such a range of services, it is first important to ask the question: Which ES have been degraded by mining and which can be most improved in the post-mining landscape? Then it is necessary to pinpoint existing demand for such services. Subsequently, various scenarios can be discussed on the preferred kind of ES, whether related to biodiversity, climate regulation, freshwater provision, fiber or food production (cp. Larondelle and Haase 2012). Following this approach, results can be systematically evaluated and the effects of measures appraised. In summary, we can say that the GI concept is a means to optimize urban, regional and landscape planning.

\section{Conclusions}

The findings of this paper illustrate the potential of the GI concept for the development of post-mining landscapes. The case study regions help to reveal the strengths and versatility of the GI concept. Four basic advantages can be highlighted: Firstly, the concept allows a systematic and highly objective assessment of mining impacts on the ecosystem, free of commercial and other individual interests. Secondly, the GI concept facilitates the incorporation of sustainable urban development goals, for instance those of the United Nations Sustainable Development Goals (UN 2015). Thirdly, the concept is rooted in the local characteristics of landscapes, allowing a tailor-made GI approach for regions in different parts of the world. Lastly, the concept seems to be highly compatible with tools of landscape and regional planning, fitting well with the application of Strategic Environmental Assessment (SEA). Clearly, further basic research has to be undertaken on how best to integrate the concept of GI in post-mining development, including a consideration of institutional framework conditions.

Restoration plans for former coal-mining areas should focus on upgrading areas of subsidence, mining heaps and brownfields to new (secondary) habitats and green areas, both as compensation for the lost (primary) pre-mining habitats and to create new potential for the successful postmining development of the region. At the same time it is vital to develop methods of GI assessment for innovative post-mining concepts. Individual case studies such as Zwickau-Lugau-Oelsnitz, Germany, and Xuzhou, China, could serve as role models for this research, not just in these two countries but also at an international level. The GI concept can help foster the sustainable development of post-mining areas, providing a good quality of life and new perspectives for local people.

Acknowledgements The basic research for the Chinese case study was supported by the National Natural Science Foundation of China (NSFC), which funded the project "Research on Space-Time Evolution Laws and Optimization Model of green infrastructure in Coal Resource Based Cities"(No. 41671524). In the German case study, the basic research was supported by the European Union's Interreg programme CENTRAL EUROPE (ReSource project). The authors would like to thank these two organizations.

Open Access This article is distributed under the terms of the Creative Commons Attribution 4.0 International License (http://crea tivecommons.org/licenses/by/4.0/), which permits unrestricted use, distribution, and reproduction in any medium, provided you give 
appropriate credit to the original author(s) and the source, provide a link to the Creative Commons license, and indicate if changes were made.

\section{References}

Ache P (2000) Cities in old industrial regions between local innovative Milieu and Urban Governance-reflections on City Region Governance. Eur Plan Stud 8(6):693-709. https://doi.org/ $10.1080 / 713666434$

Arnfield AJ (2003) Two decades of urban climate research: a review of turbulence, exchanges of energy and water, and the urban heat island. Int J Climatol 23:1-26. https://doi.org/10.1002/joc.859

Bastian O, Lupp G, Syrbe RU, Steinhäußer R (2013) Ecosystem services and energy crops-spatial differentiation of risks. Ecológia 32(1):13-29

Berrios D, Kolitsch S (2001) Untersuchung von Sickerwässern der Steinkohlenhalden im Raum Oelsnitz (Investigation of leakage water in coal mining dumps in the Oelsnitz area). TU Bergakademie Freiberg

BMUB (2017) Weißbuch Stadtgrün. Grün in der Stadt-Für eine lebenswerte Zukunft. Bundesministerium für Umwelt, Naturschutz, Bau und Reaktorsicherheit (Federal Ministry for Environment, Nature Conservation, Building and Nuclear Safety). http://www.bmub.bund.de/fileadmin/Daten_BMU/ Pools/Broschueren/weissbuch_stadtgruen_bf.pdf. Accessed 15 Aug 2017

BMWi (2015) Wismut-landscapes designed and preserved. German Federal Ministry for Economic Affairs and Energy http://www. wismut.de/www/webroot/de/download.php?download=3509. Accessed 28 March 2017

Cao X (2007) Regulating mine land reclamation in developing countries: the case of China. Land Use Policy 24:472-483. https://doi.org/10.1016/j.landusepol.2006.07.002

Cao X (2017) Policy and regulatory responses to coalmine closure and coal resources consolidation for sustainability in Shanxi, China. J Clean Prod 145:199-208. https://doi.org/10.1016/j. jclepro.2017.01.050

Chang J, Feng S (2008) Strategies on redevelopment of mining city industrial wasteland. Urban Dev Stud 2:54-57

Chang J, Koetter T (2005) From abandoned mine land to landscape park. J China Coal Soc 30:399-402

Chang J, Yang Y (2015) Suitability evaluation of abandoned mine lands supported by GIS: a case study of Yangzhuang mining area in Huaibei. In: Hu ZQ (ed) Legislation technology and practice of mine land reclamation. CRC Press, London, pp 117-125

Chang J, Wende W, Luo P, Deng Y (2011) Re-use of the mining wasteland. Tongji University Press, Shanghai

Chen N, Peng W, Xiao D, Lei Q (2010) Selective solar tunnel-concept and experiment. Acta Energ Sol Sin 31(4):442-446

European Union (2013) Green infrastructure (GI)—enhancing Europe's Natural Capital. COM (2013)249 communication green infrastructure. https://biobs.jrc.ec.europa.eu/sites/default/ files/generated/files/policy/COM\%282013\%29249\%20Commu nication\%20Green\%20Infrastructure.pdf. Accessed 31 Mar 2017

Felix M, Sohr A, Riedel P, Assmann L (2009) Gefährdungspotenzial Steinkohlenhalden Zwickau/Oelsnitz. Kurzbericht (Risk potential of hard coal mining dumps in Zwickau/Oelsnitz. Summary report). http://www.umwelt.sachsen.de/umwelt/download/luft/ 42_Kurzbericht_SteinkohlenHalden_SN.pdf. Accessed 9 Aug 2017

Feng S, Chang J, Hou W (2016) A framework for setting restoration priorities for coal subsidence areas based on green infrastructure (GI). Acta Ecol Sin 36(9):2724-2731
Firehock K (2010) A short history of the term green infrastructure and selected literature [WWW Document]. http://www.gicinc.org/ PDFs/GI\%20History.pdf. Accessed 22 Feb 2018

Grunewald K, Bastian O (2015) Ecosystem services-concept, methods and case studies. Springer, Berlin

Grunewald K, Li J, Xie G, Kümper-Schlake L (2017) Towards Green Cities Urban biodiversity and ecosystem services in China and Germany. Springer, Berlin

Haase D, Larondelle N, Andersson E, Artmann M, Borgström S, Breuste J, Gomez-Baggethun E, Gren A, Hamstead Z, Hansen R, Kabisch N, Kremer P, Langemeyer J, Rall EL, McPhearson T, Pauleit S, Qureshi S, Schwarz N, Voigt A, Wurster D, Elmqvist $\mathrm{T}$ (2014) A Quantitative review of urban ecosystem service assessments: concepts, models, and implementation. Ambio 43:413-433. https://doi.org/10.1007/s13280-014-0504-0

Haines-Young R (2013) Common international classification of ecosystem services (CICES): Consultation on version 4 August-December 2012. Report to the European Environmental Agency https://cices.eu/content/uploads/sites/8/2012/07/CICESV43_Revised-Final_Report_29012013.pdf. Accessed 11 Aug 2017

Hansen R, Pauleit S (2014) From multifunctionality to multiple ecosystem services? A conceptual framework for multifunctionality in green infrastructure planning for urban areas. Ambio 43:516-529. https://doi.org/10.1007/s13280-014-0510-2

Harfst J, Wirth P (2011) Structural change in former mining regions: problems, potentials and capacities in multi-level-governance systems. Procedia Soc Behav Sci 14:167-176. https://doi.org/10. 1016/j.sbspro.2011.03.033

Harfst J, Wirth P (2012) Zwickau-Lugau-Oelsnitz (Germany)-the long shadow of mining. In: Wirth P, Černič Mali B, Fischer W (eds) Post-mining regions in central Europe. problems, potentials, possibilities. Oekom, Munich, pp 118-128

Hennek F, Unselt C (2002) Sicherung von Naturschutzflächen in Bergbaufolgelandschaften. Landwirtschaftsverlag Münster

Hoth K, Brause H, Döring H et al (2009) Die Steinkohlenlagerstätte Zwickau (The hard coal deposit Zwickau). Bergbau in Sachsen (Mining in Saxony) https://publikationen.sachsen.de/bdb/artikel/ 12184/documents/15040. Accessed 16 Aug 2017

Krekel C, Kolbe J, Wüstemann H (2016) The greener, the happier? The effect of urban land use on residential well-being. Ecol Econ 121:117-127. https://doi.org/10.1016/j.ecolecon.2015.11.005

Larondelle N, Haase D (2012) Valuing post-mining landscapes using an ecosystem services approach - an example from Germany. Ecol Ind 18:567-574. https://doi.org/10.1016/j.ecolind.2012.01. 008

Lin ZR, Chang J, Wang W (2009) Research on planning of subsidence land's ecological restoration in Xuzhou Mining Area under the Framework of urban-rural coordination. Mod Urban Res 10:91-95

Lintz G, Wirth P (2009) The importance of Leitbilder for structural change in small towns. In: Strubelt W (ed) Guiding principles for spatial development in Germany, German annual of spatial research and policy. Springer, Berlin, pp 75-95

Lockie S, Franettovich M, Petkova-Timmer V, Rolfe J, Ivanova G (2009) Coal mining and the resource community cycle: a longitudinal assessment of the social impacts of the Coppabella coal mine. Environ Impact Assess Rev 29:330-339. https://doi. org/10.1016/j.eiar.2009.01.008

Luo PJ, Chen N (2011) Abandoned coal mine tunnels: future heating/ power supply centers. Min Sci Technol V21(5):637-640. https:// doi.org/10.1016/j.mstc.2011.10.011

Lupp G, Steinhäußer R, Bastian O, Syrbe RU (2015) Impacts of increasing bioenergy use on ecosystem services on nature and society exemplified in the German district of Goerlitz. Biomass Bioenergy 83:131-140 
Ma BG, Hu ZQ (2015) Bioremediation of acid-mine drainage contaminated with acid and heavy metals in coal mine by sulfate-reducing bacteria. In: Hu ZQ (ed) Legislation, technology and practice of mine land reclamation. CRC Press, London, pp 423-427

Maraja R, Barkmann J, Tscharntke T (2016) Perceptions of cultural ecosystem services from urban green. Ecosyst Serv 17:33-39. https://doi.org/10.1016/j.ecoser.2015.11.007

Mell I (2008) Green infrastructure: concepts and planning. FORUM Ej 8:69-80

Müller B, Finka M, Lintz G (2005) Rise and decline of industry in central and eastern Europe. Springer, Berlin

Panduro TE, Veie KL (2013) Classification and valuation of urban green spaces - $\mathrm{a}$ hedonic house price valuation. Landsc Urban Plann 120:119-128. https://doi.org/10.1016/j.landurbplan.2013. 08.009

Pauleit S, Liu L, Ahern J, Kazmierczak A (2011) Multifunctional green infrastructure planning to promote ecological services in the city. In: Niemelä J (ed) Handbook of urban ecology. Oxford University Press, New York, pp 272-285

People's Government of Jiangsu Province (2008) Opinions about acceleration of the revitalization of the old industrial base of Xuzhou (in Chinese language). http://www.jiangsu.gov.cn/jsgov/ tj/bgt/201311/t20131104405504.html. Accessed 16 Aug 2017

Rouse DC, Bunster-Ossa IF (2013) Green infrastructure: a landscape approach. American Planning Association, New York

Shen S, Lin L, Jiang G (2012) Theoretical and empirical of urban planning assessment. Southeast University Press, Nanjing

Smyth R, Mishra V, Qian X (2008) The environment and well-being in urban China. Ecol Econ 68(1):547-555. https://doi.org/10. 1016/j.ecolecon.2008.05.017

Syrbe RU (2015) Recultivation and sustainable development of postmining landscapes. In: Hu ZQ (ed) Legislation, technology and practice of mine land reclamation. CRC Press, London, pp 489492

UN (2015) United Nations Sustainable Development Goals [WWW Document]. http://www.un.org/sustainabledevelopment/sustain able-development-goals/. Accessed 16 Feb 2018

Wang W, Li J, Wang E, Zhang L, Cao Y, Xu H (2015) Introduction of Sponge City construction. Constr Sci Technol 01:19-21 (in Chinese)

Wang WL, Zhang M, Shi Q (2016) Research on replication mechanism of "ecological restoration for coal mining area Xuzhou model”. Coal Econ Res 36:27-31
WBGU (2016) Humanity on the move: unlocking the transformative power of cities. Wissenschaftlicher Beirat der Bundesregierung Globale Umweltveränderungen (German advisory council on global change), Berlin

Weller B, Naumann T, Jakubetz S (2012) Gebäude unter den Einwirkungen des Klimawandels. REGKLAM-Publikationsreihe, Heft 3, Rhombos, Berlin

Wende W (2011) Ecological potential and environmental planning of post-mining landscapes-Germany as a role model for China. In: Chang J, Wende W, Luo P, Deng Y (eds) Re-use of the mining wasteland. Tongji University Press, Shanghai, pp 22-39

Wende W (2015) Environmental planning of post-mining landscapes. In: Hu ZQ (ed) Legislation, technology and practice of mine land reclamation. Proceedings of the Beijing international symposium land reclamation and ecological restoration, CRC Press, pp 471474

Wende W, Marschall I, Heiland S, Lipp T, Reinke M, Schaal P, Schmidt C (2009) Umsetzung von Maßnahmenvorschlägen örtlicher Landschaftspläne. Naturschutz und Landschaftsplanung 41(5):145-149

Wichtmann W, Schröder C, Joosten H (2016) Paludiculture-productive use of wet peatlands. Climate protection-biodiversityregional economic benefits. Schweizerbart Science Publishers, Stuttgart

Wirth P, Lintz G (2007) Strategies of rehabilitation and development in European mining regions. In: Good (Best) practice cases in regional development after mining and industry. Symposium, May 17-18, 2006, Institute of Geography and Regional Science, University of Graz, Austria. Graz: Institut f. Geographie u. Raumforschung d. Universität, (Grazer Schriften für Geographie und Raumforschung; 42):75-85

Wirth P, Černič Mali B, Fischer W (2012) Post-mining regions in central Europe-problems, potentials, possibilities. oekom Verlag, München

Wissen M (2001) Strukturpolitische Intervention und ungleiche Entwicklung. Zur Rolle des Staates im Strukturwandel. Geographische Revue 3(1):3-22

Wright $\mathrm{H}$ (2011) Understanding green infrastructure: the development of a contested concept in England. Local Environ 16:1003-1019. https://doi.org/10.1080/13549839.2011.631993

Zhang XH (2015) Application of ground cover plants in main island of Pananhu Wetland Park. J Anhui Agric Sci 43:4-10 